\title{
Red Cabbage Extracts as Inhibitors of Lipid Oxidation in Fresh Minced Tilapia (Nile perch) During Refrigerated Storage
}

\begin{tabular}{|c|c|}
\hline \multicolumn{2}{|c|}{ 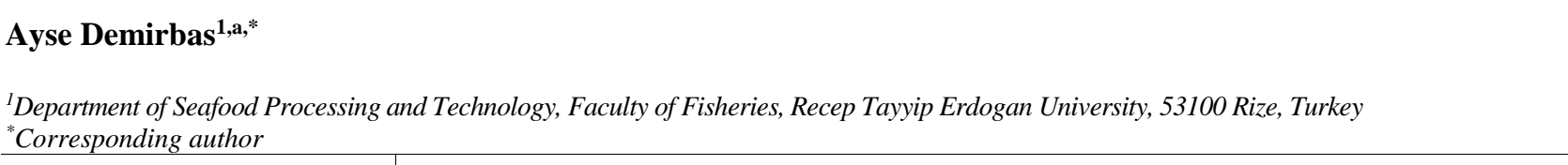 } \\
\hline A R T I C LE I N F O & A B S T R A C T \\
\hline $\begin{array}{l}\text { Keywords: } \\
\text { Natural antioxidant } \\
\text { Shelf life } \\
\text { Fish } \\
\text { Red cabbage } \\
\text { Lipid oxidation }\end{array}$ & $\begin{array}{l}\text { This study was performed to evaluate effects of red cabbage extract as a preservative against lipid } \\
\text { oxidation for quality and shelf life of minced Tilapia (Nile perch) during refrigerated storage at } 4 \pm \\
1{ }^{\circ} \mathrm{C} \text {. Untreated and treated samples were examined from day } 0 \text { to } 10 \text { during refrigerated storage } \\
\text { using thiobarbituric acid reactive substances (TBARS) assay, peroxide value (PV), pH and color } \\
\text { analysis. Samples treated with red cabbage extract showed less degradation due to lipid oxidation } \\
\text { compared to untreated samples. Lipid peroxide values on treated samples showed benefits through } \\
\text { day- } 6 \text {. This work shows that red cabbage antioxidant extracts represent an inexpensive and natural } \\
\text { method for reducing oxidative spoilage of fresh fish. }\end{array}$ \\
\hline
\end{tabular}

\section{Introduction}

The importance of fish and seafood products, rich in long chain omega-3 fatty acids (docosahexaenoic acid and eicosapentaenoic acid), protein, vitamin $\mathrm{D}$, and minerals is well documented (Faber, 2010; Sheeshka, 2002; Jaclyn, 2010; Bate 1956).

Tilapia (Nile perch) is one of the most cultivated species in the world. Tilapia are vegetarian so they only eat algae and plants resulting in low mercury content compared to the other seafood products. Tilapia are easy to debone and offer delicate flavour and good nutritional quality. Tilapia is a small fish compared to salmon or tuna and it grows relatively fast, reaching maturity in about 9 months compared to 2 and 4 years for salmon and tuna, respectively (Dergal, 2013; Yanar, 2006; Boari, 2008).

The major factors of spoilage in fish are enzymatic activity, bacteria and chemicals present on and in fish. Other factors also contribute to spoilage of fish including high moisture content, high fat content, high protein content, weak muscle tissue, ambient temperature and less than hygienic handling (Bate, 1956; Watanabe, 1991; Burt, 1976; Gopakumar, 2000; Karube 1984; Lima Dos Santos, 1984).

However, lipid oxidation and associated rancid offflavours remain the most significant cause of consumer objection of fish and foodstuff including fish oils (Pazos, 2005; Buaneow, 2008; Kanner 1994; Gandemer 1995).

To solve mitigate effects of lipid oxidation, natural and synthetic antioxidants have been used to prevent oils, and particularly fish oils, from becoming rancid prior to consumption (Pazos, 2005). Given growth of natural and organic foods, there is interest in natural antioxidants for use in foods. For instance, Pazos et al. (2005) applied grape polyphenols to fish lipids and frozen muscle and found that flavonol oligomers were the most potent inhibitors of oxidation in emulsions and frozen fish muscle. According to Sa'nchez-Alonso et al. (2007), addition of red grape fibre delayed lipid oxidation in minced horse mackerel muscle during the first 3 months of frozen storage. In another study, white grape antioxidant activity was examined on lipid oxidation in minced horse mackerel muscle during frozen storage and results showed that $2 \%$ white grape dietary fibre (WGDF) inhibited development of oxidation in minced horse mackerel muscle during storage at $-20^{\circ} \mathrm{C}$ (Sa'nchez-Alonso, 2008).

Use of rosemary and thyme plant extracts for delaying lipid oxidation has been reported in several studies (Khalafalla, 2015; Afanso, 2008). 
Maqsood et al. (2010) reported a comparative antioxidant study of different phenolic compounds (catechin, caffeic acid, ferulic acid and tannic acid) at various levels determined by different assays (Maqsood, 2010). Numerous studies have reported antioxidant properties of herbs, spices and plant extract as natural additives (Sa'nchez-Alonso, 2007; Sa'nchez-Alonso, 2008; Khalafalla, 2015; Afanso, 2008; Maqsood, 2010; Raghavan, 2005; Maqsood, 2013; Tang, 2001; Yarnpakdee, 2012).

Some studies show that different amounts of anthocyanins in red cabbage such as 11 anthocyanins, 20 anthocyanins, 24 anthocyanins or 36 anthocaynins have been obtained from red cabbage using HPLC- MS or MS/MS (High performance liquid Chromatography \& Mass spectra) (McDougall, 2007; Wlczkowski, 2013; Arapitsas, 2008; Charran, 2007). Most scientists emphasize that the major anthocyanins in red cabbage are based on a core of Cyanidin-3-O-diglucoside-5-Oglucoside, which can be non-acylated, mono-acylated or di-acylated with p-coumaric, caffeic, ferrulic and sinapic acids (Wiczkowski, 2015; Pliszka, 2009; Podsedek, 2008; Piccaglia, 2002). Moreover, red cabbage represents an alternative to grape due to properties of acylation, which gives greater stability to heat and light than grape anthocyanins. Anthocyanins from red cabbage may be better suited for the food sector than grape simply due to wider availability (Henry, 1996; Shimizu, 1997). According to Simon et al., another advantage is that red cabbage is safer than grape because grape pomace may contain residues of sulphur dioxide that is used in winemaking from grape, which can cause allergic reactions in some people (Simon, 1998).

Therefore, the objective of this work was to investigate antioxidant effects of red cabbage extracts on lipid oxidation in fresh minced tilapia fish.

\section{Materials and Methods}

\section{Chemicals}

All chemicals (methanol, chloroform, ammonium thiocyanate, ferrous chloride, Folin \& Ciocalteu's phenol reagent $(2 \mathrm{~N})$, cumene hydroperoxide, gallic acid, ascorbic acid, potassium chloride, sodium acetate, sodium carbonate, 6-hydroxy-2, 5, 7, 8-tetramethylchroman-2carboxylic acid (Trolox), 2,2-diphenyl-1-picrylhydrazyl (DPPH)) used were analytical grade and were purchased from Fisher-Scientific (Fair Lawn, NJ, USA) and SigmaAldrich Co (St. Louis, MO, USA).

\section{Preparation and Storage of Fish Patties}

Fresh tilapia fillets were purchased from local fish market (Northwest Seafood, Inc., Gainesville, Florida) and fresh red cabbage plants were purchased from a local organic market in Gainesville, Florida. Red cabbage extracts were stored in a $-20^{\circ} \mathrm{C}$ freezer. Fresh tilapia fillets were minced using a meat mincer (STX turbo force, $3000 \mathrm{~W}, \mathrm{USA}) .50 \mathrm{~g}$ ground fish samples were treated with different amounts of red cabbage extract 17, 34, 68 ppm red cabbage extract solution. 500ppm gallic acid and $500 \mathrm{ppm}$ ascorbic acid were separately used as positive controls on $900 \mathrm{~g}$ minced fish. Minced fish samples were stored under refrigeration $\left(4 \pm 1^{\circ} \mathrm{C}\right)$ for testing.

\section{Extraction of Red Cabbage}

Extracts of red cabbage were freeze concentrated. 100 $\mathrm{g}$ chopped red cabbage was added to $100 \mathrm{~mL}$ DI water and boiled for 1 hour. The liquid phase was vacuum filtered and centrifuged. Filtered extract was frozen in a $-80^{\circ} \mathrm{C}$ freezer and then thawed for $5 \mathrm{~min}$ to collect concentrated anthocyanin from frozen water ice.

\section{Total Polyphenols Colorimetric Assay}

Total phenolic content of each extract was determined by the Folin-Ciocalteu colorimetric method of Singleton et al. (1965). A mixture of $100 \mu \mathrm{L}$ red cabbage extract and $3900 \mu \mathrm{L}$ distilled water, $250 \mu \mathrm{L}$ Folin-Ciocalteau reagent $(2 \mathrm{~N})$, and $750 \mu \mathrm{L} 20 \% \mathrm{Na}_{2} \mathrm{CO}_{3}$ were mixed in a tube. Samples and standards were incubated for 30 minutes in a $40^{\circ} \mathrm{C}$ water bath and absorbance was measured at $760 \mathrm{~nm}$. Gallic acid (GA) was used as standard and expressed as Gallic acid equivalents (mg GAE/g DM, mg gallic acid/g of dry defatted matter) using an external calibration curve. The linearity range of the calibration curve was $100-800 \mathrm{ug} / \mathrm{mL}$.

\section{Total Antioxidant Activity by DPPH Assay}

Antioxidant activity of each extract was evaluated using the DPPH radical scavenging capacity assay following procedure of Brand-Williams et al. (1995). The stock solution was prepared by dissolving $24 \mathrm{mg}$ DPPH with $100 \mathrm{~mL}$ methanol (DPPH Solution $=0.025 \mathrm{~g} / 100 \mathrm{~mL}$ methanol) and then stored at $-20^{\circ} \mathrm{C}$ until needed. The working solution was obtained by mixing $10 \mathrm{~mL}$ stock solution with $45 \mathrm{~mL}$ methanol to obtain an absorbance of $1.1 \pm 0.02$ units at $515 \mathrm{~nm}$ of blank (methanol) and test sample using a spectrophotometer (Beckman Instruments, CA, USA). Red cabbage extracts $(100 \mu \mathrm{L})$ were reacted with $3900 \mu \mathrm{L}$ of the DPPH solution for 60 minutes in the dark at room temperature. Meanwhile, $100 \mu \mathrm{L}$ trolox solution with respective concentrations 100, 200, 400, 600, $800,1000 \mu \mathrm{M}$ were added to $3.9 \mathrm{~mL}$ DPPH working solution for generating the standard curve. Absorbance was recorded at $515 \mathrm{~nm}$ by an ultraviolet-visible Beckman Coulter DU-640 spectrophotometer (Beckman Instruments, CA, USA). Results were expressed in $\mu \mathrm{M}$ $\mathrm{TE} / \mathrm{g}$ fresh mass.

Free radical scavenging activity was calculated using the following equation:

$\%$ Inhibition $=\left(\mathrm{A}_{\text {control }}-\mathrm{A}_{\text {sample }}\right) / \mathrm{A}_{\text {control }} \times 100$

\section{Total Anthocyanin by pH Differential Method}

Total anthocyanin content in red cabbage extracts was measured by the $\mathrm{pH}$ differential method of Jungmin Lee et al. (2005).

Two buffer systems were used including potassium chloride buffer $(0.025 \mathrm{M}, \mathrm{pH}=1.0)$ and sodium acetate buffer $0.4 \mathrm{M}, \mathrm{pH}=0.4)$. An aliquot of the red cabbage extract $(1.0 \mathrm{~mL})$ was placed in a $20 \mathrm{~mL}$ volumetric flask, diluted to volume with $\mathrm{pH} 1.0$ buffer and mixed. A second aliquot of the red cabbage extract $(1.0 \mathrm{~mL})$ was placed to a $20 \mathrm{~mL}$ volumetric flask, diluted to volume with $\mathrm{pH} 4.5$ buffer and mixed. Both solutions were incubated at room temperature for 20 minutes. Then the prepared solutions were measured by using UV/VIS spectrophotometer at 510 
$\mathrm{nm}$ and $700 \mathrm{~nm}$. Absorption was calculated according to the equation 1 and expressed as $\mathrm{mg}$ of cyanidin-3glucoside per gram red cabbage leaves.

$$
\mathrm{AP}=\left(\mathrm{A} \times \mathrm{MW} \times \mathrm{DF} \times 10^{3}\right) / \dot{\varepsilon} \times \mathrm{I}
$$

Where,

$$
\begin{aligned}
\mathrm{AP} & =\text { Anthocyanin pigment }(\text { cyaniding-3-glucoside }, \\
& \mathrm{mg} / \mathrm{L}) \\
\mathrm{A} & =(\mathrm{A} 510-\mathrm{A} 700) \mathrm{pH} 1.0-(\mathrm{A} 510-\mathrm{A} 700) \mathrm{pH} 4.5 \\
\mathrm{MW} & =\text { molecular weight }=611 \mathrm{~g} / \mathrm{mol} \text { for cyanidin-3,5- } \\
& \text { diglucoside } \\
\mathrm{DF} & =\text { is dilution factor established in } \mathrm{D}, \\
\mathrm{I} & =\text { Path Length in cm, } \\
\dot{\varepsilon} & =30,175 \text { molar extinction coefficient in } \mathrm{L} \times \text { mol- } \\
& 1 \times \mathrm{cm}-1, \text { for cyanidin-3,5-diglucoside } \\
10^{3} & =\text { factor for conversion from gram to milligram. }
\end{aligned}
$$

\section{Colour Analysis by Machine Vision}

Colour analysis involved the method of Luzuriaga, (1997); Yoruk, (2004); Yagiz, (2009); Yagiz, (2010). Surface colour of treated and untreated (control) fresh tilapia patties was measured during storage by the machine vision (Figure 1). The machine vision system was comprised of a fluorescent light box $(42.5 \mathrm{~cm} \mathrm{(w)} \times 61 \mathrm{~cm}(\mathrm{l}) \times 11.4 \mathrm{~cm}(\mathrm{~h}))$ and used a digital Nikon D200 colour camera (Nikon D200 Digital Camera, Nikon Corp., Japan) connected to a computer with a fire wire connection. Camera settings were $36 \mathrm{~mm}$ focal length, ISO 100 sensitivity, 1/3 s F/11 shutter speed, × $1.0 \mathrm{EV}$ exposure compensation, and direct sunlight white balance. Average daylight illuminate D65 mode with a color temperature of $6504 \mathrm{~K}$ was used. Results were reported based on $L^{*}$ (lightness), $a^{*}$ (redness), $b^{*}$ (yellowness) values for analysing total colour difference $\Delta \mathrm{E}^{*}$ (Luzuriaga, 1997; Yoruk, 2004; Yagiz, 2009; Yagiz, 2010).

Fish patties were placed in the light box and the digital camera captured images of patties each day. The vision system was calibrated using a standard light skin plate $\left(L^{*}\right.$ $=63.84, a^{*}=19.8$ and $b^{*}=15.79$ ) (Minolta) and using a professional camera calibration target as reference. Average $L^{*}, a^{*}, b^{*}$ values and $\Delta \mathrm{E}^{*}$ (total colour differences) were calculated against the light pink standard $\left(L^{*} 63.84, a^{*} 19.8\right.$ and $\left.b^{*} 15.79\right)$.

\section{Lipid and Moisture Content}

Moisture content was determined using a Cenco moisture balance (CSC Scientific Co. Inc., Fairfax, Va., U.S.A.). Lipids were extracted and quantified according to the method of Bligh and Dyer (Bligh, 1959).

\section{Thiobarbituric Acid Reactive Substances (TBARS)}

TBARS was performed based on a modification of Lemon et al. (1974), according to Raghavan (2005), by measuring secondary products of oxidation in tilapia muscle. Approximately $1 \mathrm{~g}$ tilapia muscle and $3 \mathrm{~mL}$ of $7.5 \%$ TCA solution were homogenized for $1 \mathrm{~min}$ in a disposable glass tube. Samples were centrifuged (Beckman Instruments, CA, USA) at $2000 \mathrm{rpm}$ for $10 \mathrm{~min}$. A $2 \mathrm{~mL}$ aliquot of supernatant was mixed with $2 \mathrm{~mL}$ of $0.02 \mathrm{M}$ TBA solution and heated in a boiling water bath for $40 \mathrm{~min}$. Samples were cooled in an ice and tap water container. Colour was measured using UV-Vis Spectrophotometre at $530 \mathrm{~nm}$. A standard plot was prepared using tetraethoxypropane (TEP).

\section{Peroxide Value (PV)}

PV was measured according to the method of Raghavan and Hultin (2005) by measuring by measuring primary products of oxidation in tilapia muscle. Approximately $1 \mathrm{~g}$ of tilapia muscle was homogenized for $1 \mathrm{~min}$ using a handheld homogenizer in $10 \mathrm{~mL}$ of chloroform/methanol $(2: 1)$ and then $3 \mathrm{~mL}$ of $0.5 \% \mathrm{NaCl}$ solution was added. The mixture was vortexed for $30 \mathrm{sec}$ and then centrifuged at $2000 \mathrm{rpm}$. Two $\mathrm{ml}$ chloroform was used to dilute to $10 \mathrm{~mL}$ mix of chloroform/methanol (2:1). Ammonium thiocyanate and ferrous chloride were prepared as in Shantha (1994). A $25 \mu \mathrm{L}$ aliquot of each reagent was added and vortexed for $10 \mathrm{~s}$. Samples were incubated for $10 \mathrm{~min}$ at room temperature, and absorbance was measured at 500 nm. A standard curve was prepared using cumene hydroperoxide $\left(\mathrm{C}_{9} \mathrm{H}_{12} \mathrm{O}_{2}\right)$.

\section{pH Values}

The $\mathrm{pH}$ was determined according to Vareltzis et al. (1988), using $1 \mathrm{~g}$ fish sample. $1 \mathrm{gr}$ of minced tilapia meat and $9 \mathrm{~mL}$ distilled water were homogenized by a hand-held homogenizer (Biohomogenizer M 133/1281-0 2 Speed $(115 \mathrm{~V}, 140 \mathrm{~W}))$. The $\mathrm{pH}$ of the mixture was measured using a $\mathrm{pH}$ meter (Fisher Scientific AB15 pH meter, USA) for each day.

\section{Statistical Analysis}

The experimental data were performed by one -and two-way ANOVA. The differences between means were evaluated by Tukey`s test $(\mathrm{P}<0.05)$. We used Microsoft Excel Version 2016 (MS Excel 2016) for data analysis.

\section{Results and Discussion}

Figure 1 shows total phenolic content of red cabbage extract as a function of thaw time (5 min, 1 hour, 5 hours, 24 hours, and ice part). Highest observed values were obtained after $5 \mathrm{~min}$ of thawing $(16.99 \mathrm{ug} / \mathrm{g}(\mathrm{FW})(\mathrm{P}<0.05)$. Figure 2 shows antioxidant activity of freeze-concentrated red cabbage extract after different thaw times. The first 5 min thawed time showed highest value antioxidant values of $2069.81 \mathrm{umol} / \mathrm{g}$ with little remaining in the water ice (123.69 umol/g). Anthocyanin content were significantly observed in $5 \mathrm{~min}$ thawed time as highest value $(25.47 \mathrm{ug} / \mathrm{g})$ compared to other thawed time (1, 5, 24 hours, and ice part of extraction) $(\mathrm{P}<0.05)$. The lowest value was $3.96 \mathrm{ug} / \mathrm{g}$ in ice part of extraction in Figure 3.

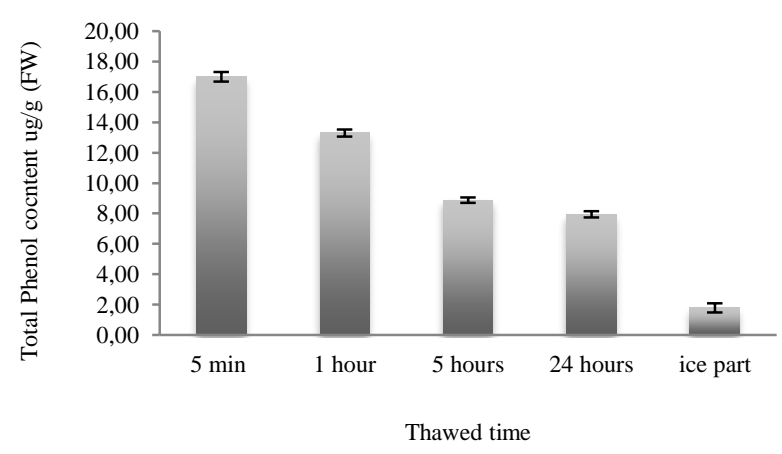

Figure 1. Total phenolic content of red cabbage extracts at different thawed times for freeze/thawed method. 


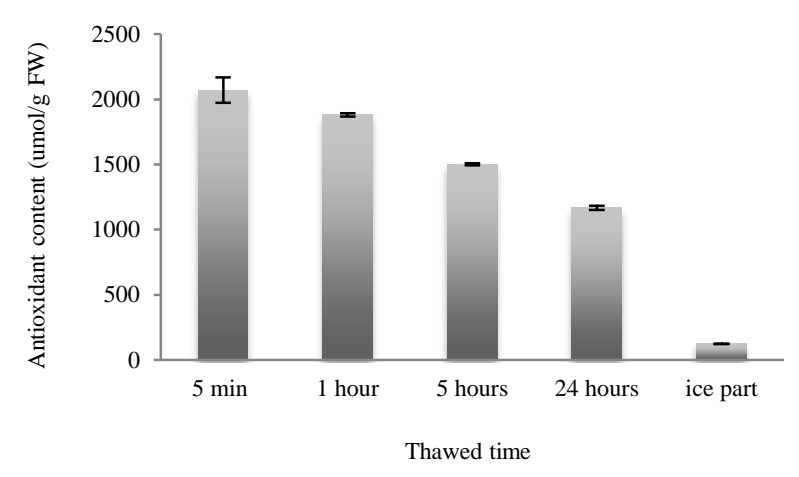

Figure 2. DPPH values of red cabbage extracts at different thaw times for freeze/thawed method.

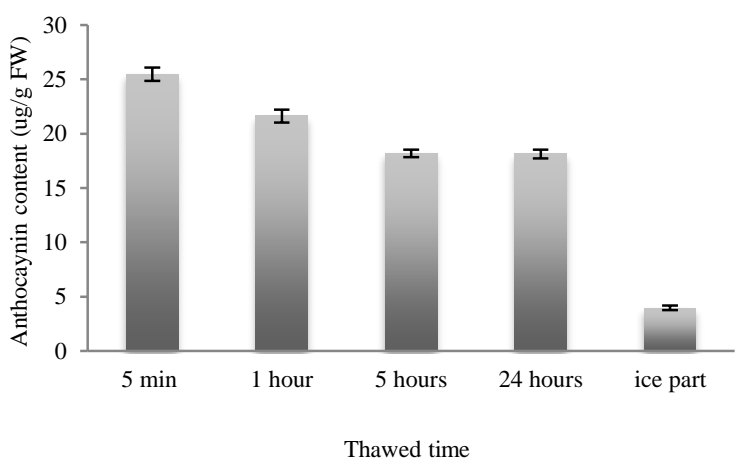

Figure 3. Anthocyanin values of freeze-concentrated red cabbage extracts at different thawed time for freeze/thawed method.

A)

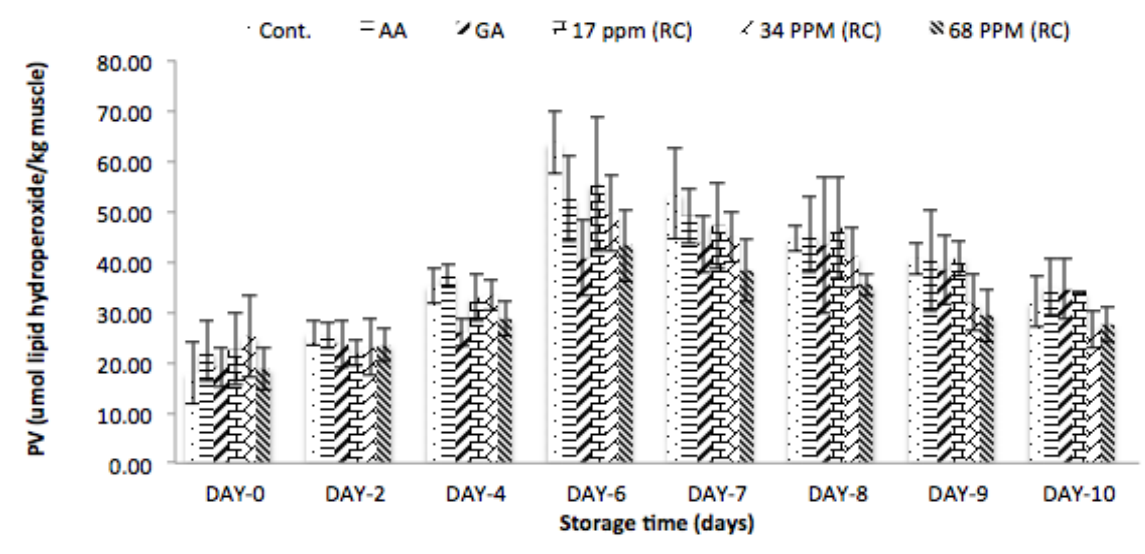

B)

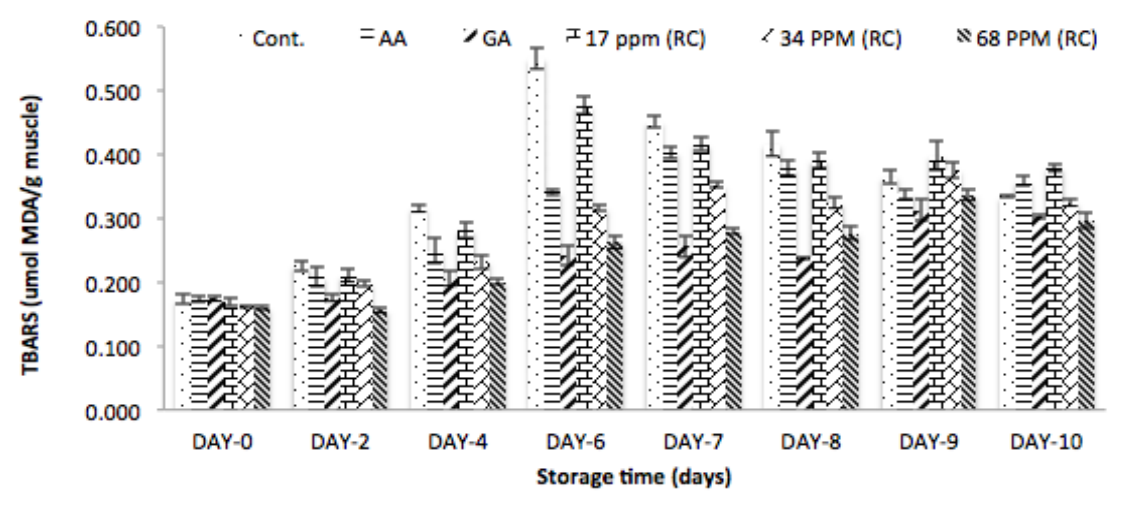

Figure 4. Changes in TBARS and PV value of minced tilapia muscle during storage. Error bars represent the standard deviations.

Results show that after freezing at $-80^{\circ} \mathrm{C}, 5$ min of thawed time resulted in highest antioxidant activity, anthocyanin amount and total phenols content $(\mathrm{P}<0.05)$ in concentrated extracts.

TBARS values of tilapia patties during refrigerated storage (Figure 4A) show continuous increase in TBARS value up to 6 days $(\mathrm{P}<0.05)$. Thereafter, TBARS values decreased notably $(\mathrm{P}<0.05)$. The TBARS value was expressed as umol malonaldehyde/g sample since Malondialdehyde (MDA) is the most abundant aldehydes generated during secondary lipid oxidation, and MDA is commonly used as oxidation marker (Shahidi, 2005).

TBARS values of controls (untreated) were 0.17 umol $\mathrm{MDA} / \mathrm{g}$ at Day 0, which reflected presence of lipid oxidation products in minced muscle after capture and during handling. This value reached $0.55 \mathrm{umol} \mathrm{MDA} / \mathrm{g}$ in controls by day. During extended storage, lipid oxidation proceeded as evidenced by the increases in TBARS values until Day $6(\mathrm{P}<0.05)$. Samples treated with $68 \mathrm{ppm}$ concentrated of red cabbage extract showed a low inhibition on the formation of TBARS, compared with the control for all storage days (Figure 4A) $(\mathrm{P}<0.05)$.

The first compounds formed during the oxidation process are peroxides, specifically hydroperoxides; thus, they are called primary oxidation products (Shahidi, 2005; Barriuso, 2013; Dobarganes, 2002; Melton, 1983).

$\mathrm{PV}$ of tilapia muscle during refrigeration storage of 10 days is shown in Figure 4B. Peroxide value (PV) increased up to Day 6 and subsequently decreased to day 10 (Figure 4B) $(\mathrm{P}<0.05)$. 

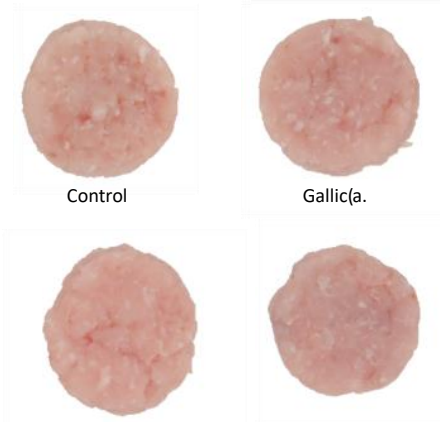

$0.5(\mathrm{~mL}(\mathrm{RC}$

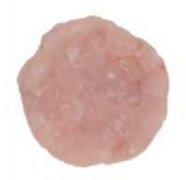

$1(\mathrm{~mL}(\mathrm{RC}$

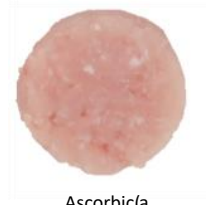

Ascorbic(a.

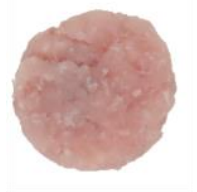

$2(m L)(R C$

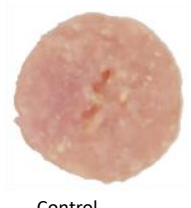

Control-

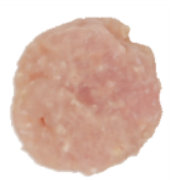

$0.5-\mathrm{mL}-\mathrm{RC}$
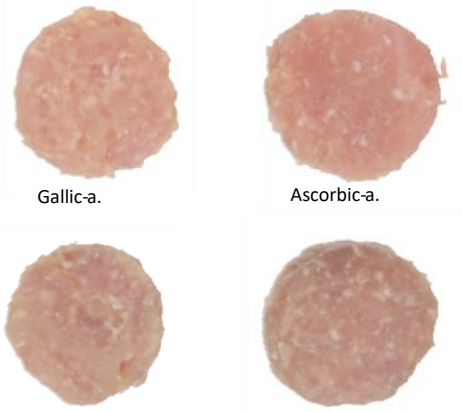

$1-\mathrm{mL}-\mathrm{RC}$

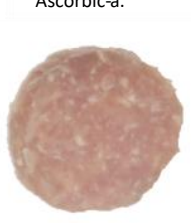

2-mL-RC

Figure 5. Pictures of tilapia patties (untreated and treated with Figure 6. Pictures of tilapia patties (untreated and treated with red cabbage antioxidants at different concentration, gallic and red cabbage antioxidants at different concentration, gallic and ascorbic acid) during refrigeration storage time (day-0) ascorbic acid) during refrigeration storage time (day-10)

A)

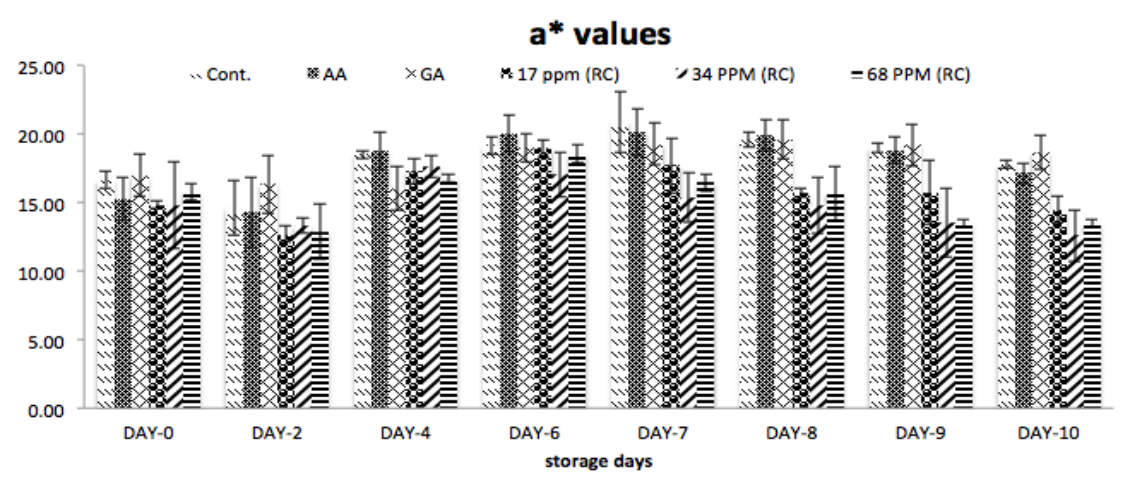

B)

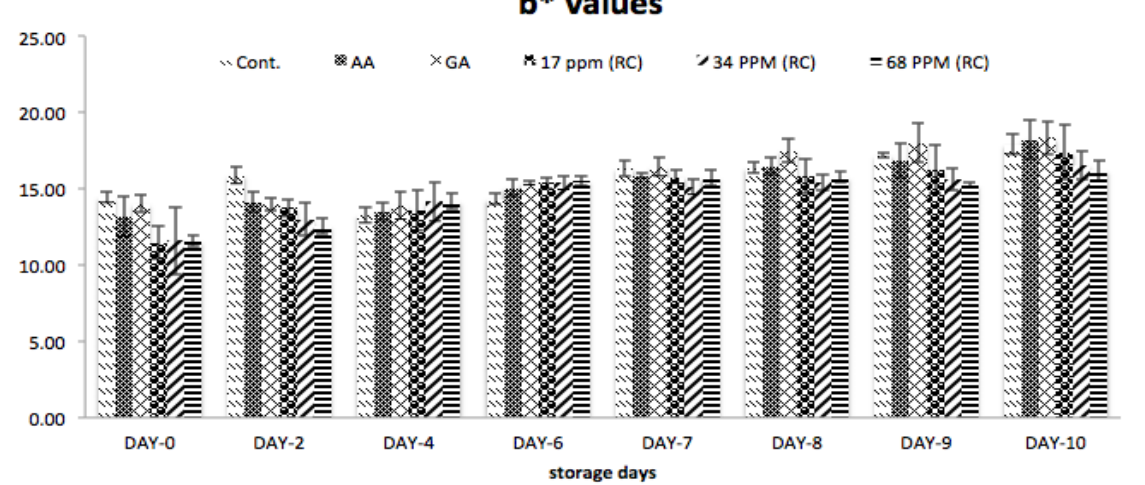

Figure 7. Changes in $a^{*}$ and $b^{*}$ values of tilapia patties (untreated and treated with red cabbage antioxidants at different concentration, gallic and ascorbic acid) during refrigeration storage time.

At Day 0, PV of controls was of 17.86 umol hydroperoxide $/ \mathrm{kg}$. PV increased through 6 days of iced storage $(\mathrm{P}<0.05)$. Subsequently, PV decreased through day $10(\mathrm{P}<0.05)$. The increase in PV was likely due to the formation of hydroperoxide during early stages of lipid oxidation. These results are in accordance with the lower PV values of gallic acid treatment as positive controls. Moreover, samples with $2 \mathrm{ml}$ concentrated of red cabbage extracted resulted in lowest PV values observed during storage $(\mathrm{P}<0.05)$. The result shows that lipid oxidation occurred during refrigerated storage, probably because of the high content of unsaturated fatty acids (Figure 4.)

Chemical composition analysis of tilapia fish was presented in Table 1. Including moisture and lipid content at day 0 (Table 1.). The literature reports higher moisture and lipid values than those the found in the present study (Yarnpakdee, 2014; Angelini, 2013). The differences between literature and present study may be attributed to environmental factors, seasons, and feeding quality of fish.

Myoglobin and hemoglobin are generally responsible for colour changes in fish flesh and oxidation of these proteins tends to cause yellow-brownish colours (Yarnpakdee, 2012; Venugopol, 1996). Decreases in a* were observed during storage after day 2 (Figure 7A). Surface redness decreased with increasing yellowness during storage for all samples $(\mathrm{P}<0.05)$. At the end of storage, yellowish discolorations were observed when compared to day $0(\mathrm{P}<0.05)$. Increases in $b^{*}$ are shown in Figure 7B. Yellowness on sample surfaces increased with decreasing redness during storage for all samples $(\mathrm{P}<0.05)$ (Figure 5 and 6). There is a significant colour change from pink to yellowness in figure 5 and 6. Lipid oxidation causes to yellow discoloration of fish muscle (Khantaphant, 2011). 
Table 1. Mean of Proximate composition of raw minced tilapia (Nile perch)

\begin{tabular}{l|c}
\hline \multicolumn{1}{c|}{ Sample component } & Minced tilapia \\
\hline Lipid & $0.039(0.002)$ \\
Moisture & $77.3(0.70)$ \\
\hline
\end{tabular}

(a) Values in parenthesis shown standard deviation.

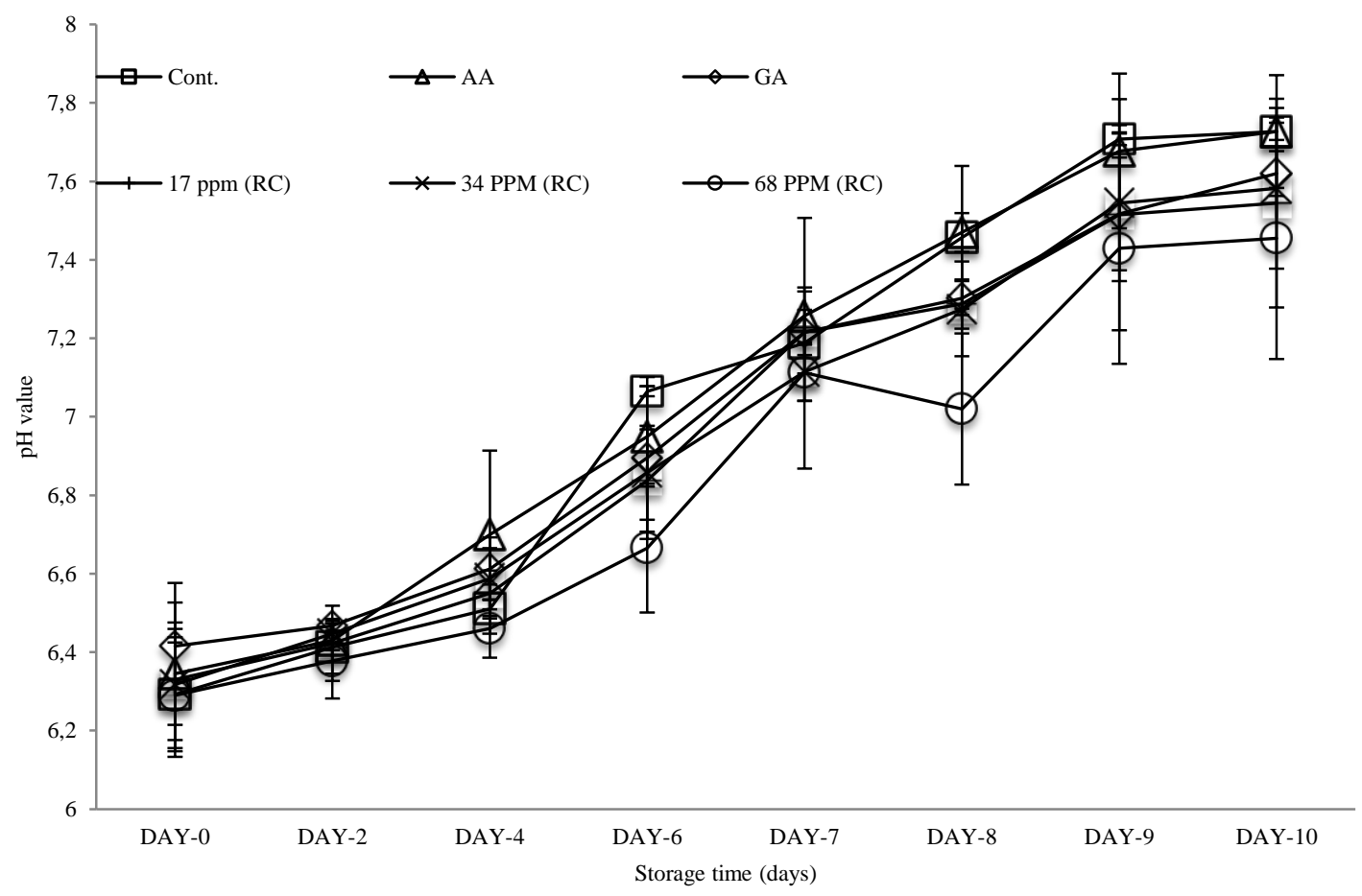

Figure 8. Changes in $\mathrm{pH}$ values of tilapia patties (untreated and treated with red cabbage antioxidants at different concentration, gallic and ascorbic acid) during refrigeration storage time.

A continuous increase in $\mathrm{pH}$ values was noticeable with increasing storage time $(\mathrm{P}<0.05)$ (Figure 8$). \mathrm{pH}$ values increased $(\mathrm{P}<0.05)$ during refrigerated storage time (Figure 8 ) in the control samples and in those treated with antioxidants (red cabbage extract, gallic and ascorbic acid).

$\mathrm{pH}$ value of fresh fish meat generally varies from 5.76.6. Fresh fish muscle is close to neutral $\mathrm{pH}$ (7.0), but after death, lactic acid is produced causing $\mathrm{pH}$ to fall initially. As spoilage occurs, $\mathrm{pH}$ tends to rise (Sa'nchez-Alonso, 2007; Bilgin, 2007; Oguzhan, 2013).

\section{Conclusion}

Results from this study showed that decreasing thawed time yielded higher polyphenols content during extraction of red cabbage. Increasing application of red cabbage extract in minced tilapia decreased lipid oxidation during refrigerated storage. This work shows that red cabbage antioxidant extracts may represent a natural antioxidant alternative for reducing oxidative spoilage of fresh fish.

\section{Acknowledgement}

Thankful to Dr. Marshall and Dr. Yavuz Yagiz for unlimited helpful in their laboratory (Food \& Environmental Toxicology Lab (FETL), Department of Food Science and Human Nutrition, University of Florida, 32611, Gainesville, FL, USA).

\section{References}

Afonso MDS, Sant'ana IS. 2008. Effects of Pretreatment with Rosemary (rosmarinus officinalis 1.) in the Prevention of Lipid Oxidation in Salted Tilapia Fillets. Journal of Food Quality, 31: 586-595.

Angelini MFC, Galvão' JÁ, Vieira ADF, Savay-da-Silva LK, Shirahigue LD, Cabral ISR, Modesta RCD, Gallo CR, Oetterer M. 2013. Shelf life and sensory assessment of tilapia quenelle during frozen storage, Pesq. agropec. bras, 48 (8).

Anthovic M, Prenzler PD, Patsalides E, Mcdonald S, Robards K. 2002. Methods for testing antioxidant activity. Analyst, 127 (1): 183-198.

Arapitsas P, Sjo"berg PJR, Turner C. 2008. Characterisation of anthocyanins in red cabbage using high resolution liquid chromatography coupled with photodiode array detection and electrospray ionization-linear ion trap mass spectrometry. Food Chemistry, 109: 219-226.

Barriuso B, Astiasaran I, Ansorena D. 2013. A review of analytical methods measuring lipid oxidation status in foods: a challenging task. Eur Food Res Technol, 236: 1-15.

Bate Smite, EC and Bendall, JR. 1956. Changes in fish muscle after death. British Medical Bulletin 12, 2305.

Bilgin S, Ertan OO, Günlü A (2007). The effects on chemical composition of Salmo trutta macrostigma Dumeril, 1858 of different salting techniques. J. Fisheries \& Aquat. Sci, 24 (34): 225-232.

Bligh EG, Dyer WJ. 1959. A rapid method of total lipid extraction and purification.

Boari CA, Pereira GI, Valeriano C, Silva BC, De Morais VM, Figueiredo HCP, Piccoli RH. 2008. Bacterial ecology of tilapia fresh fillets and some factors that can influence their microbial quality. Ciênc. Tecnol. Aliment, 28: 863-867. 
Brand-Williams W, Cuvelier ME, Berset CU. 1995. seofafreeradical method to evaluate antioxidant activity. LWT-Food Sci. Technol, 28: 25-30.

Buaneow C, Usawakesmanee W, Siripongvutikorn S, Tongraung C. 2008. Effect of $\mathrm{pH}$ and ATP on lipid oxidation in unwashed and washed seabass mince (Lates calcarifer) mediated by hemoglobin. Songklanakarin J. Sci. Technol, 30 (1): 19-23.

Burt, JR.1976. Hypoxanthine a biochemical index of fish quality. Process Biochemistry. 11 (10).

Canadian Journal of Biochemistry and Physiology, 37(8): 911917.

Charron CS, Clevidence BA, Britz SJ, Novotny JA. 2007. Effect of Dose Size on Bioavailability of Acylated and Nonacylated Anthocyanins from Red Cabbage (Brassica oleracea L. Var. capitata). J. Agric. Food Chem, 55: 5354-5362.

Dergal NB, Abi-Ayad SMEA, Degand G, Douny C, Brose F, Daube G, Rodrigues A, Scippo ML. 2013. Microbial, biochemical and sensorial quality assessment of Algerian farmed tilapia (Oreochromis niloticus) stored at 4 and $30^{\circ} \mathrm{C}$. African journal of food science, 7(12): 498-507.

Dobarganes MC, Velasco J. 2002. Analysis of lipid hydroperoxides. Eur.J. Lipid Sci. Technol, 104: 420-428.

Faber, TA, Bechtel PJ, Hernot DC, Parsons CM, Swanson KS, Smiley S, Fahey GC Jr. 2010. Protein digestibility evaluations of meat and fish substrates using laboratory, avian, and ileally cannulated dog assays. J Anim Sci, 88 (4): 1421-1432.

Gandemer, G., and Meynier, A. 1995. The importance of phospholipids in the development of flavour and off-flavour in meat products. In: Composition of meat in relation to processing, nutritional and sensory quality: from farm to fork. Lundstrom, K., Hansson, I., Wiklund, E., Eds., pp 119128.ECCEAMST: Utrecht, The Netherlands.

Gopakumar K. 2000. Seafood Enzymes: Enzymes and Enzyme products as Quality Indices, By Norman F. Haard, Benjamin K. Simpson. 337-363.

Henry BS. 1996. Natural food colors, in Natural Food Colorants, Ed by Henry GAF and Houghton JD, Blackie Academic and Professional, New York, 40-79

Heras AD, Schoch A. 2003. Comparison of methods for determining malonaldehyde in dry sausage by HPLC and the classic TBA test. Food Res. Technol., 217: 180-184.

Jaclyn MC, Stacey JB, Ashley SR. 2010. Omega-3 fatty acids and pregnancy. Obstetrics and gynecology, 3 (4): 163-171.

Jardine D, Antolovich M. 2002. Liquid Chromatography-Mass Spectrometry (LC-MS) Investigation of the Thiobarbituric Acid Reactive Substances (TBARS) Reaction. Agric. Food Chem, 50: 1720-1724.

Kanner J. 1994. Oxidative processes in meat and meat products: quality implications. Meat Sci. 36: 169-189.

Karube I, Marouka H, Suzuki S, Watanabe E, Toyana K. 1984. J.Agric and Food Chemistry. 32: 314-319.

Khalafalla FA, Ali FHM, Abdel-Rahim HAH. 2015. Quality improvement and shelf-life extension of refrigerated Nile tilapia (Oreochromis niloticus) fillets using natural herbs. Journal of basic and applied science, 4: 33-34.

Khantaphant S, Benjakul S, Ghomi MR. (2011). The effects of pretreatments on antioxidative activities of protein hydrolysate from the muscle of brownstripe red snapper (Lutjanus vitta). LWT - Food Science and Technology, 44: $1139-1148$.

Lee J, Durst RW, Wrolstad RE. 2005. Determination of total monomeric anthocyanin pigment content of fruit juices, beverages, natural colorants, and wines by the $\mathrm{pH}$ differential method: Collaborative study. Journal of AOAC international, 88: $1269-1278$.

Lemon DW. 1974. An Improved TBA test for rancidity. New Series Circular No. 51. Halifax,Nova Scotia.
Lima Dos Santos, CAM, James, D and Teutscher, F.1984. Guidelines for chilled fish storage experiments. FAO Fisheries Technical paper, No 210. FAO, Rome

Luzuriaga DA, Balaban MO, Yeralan S. 1997. Analysis of visual quality attributes of white shrimp by machine vision. J. Food Sci, 62(1): 113-118.

Maqsood S, Benjakul S, Shahidi F. 2013. Emerging Role of Phenolic Compounds as Natural Food Additives in Fish and Fish Products. Food Science and Nutrition, 53: 162-179.

Maqsood S, Benjakul S. 2010. Comparative studies of four different phenolic compounds on in vitro antioxidative activity and the preventive effect on lipid oxidation of fish oil emulsion and fish mince. Food Chemistry, 119: 123-132.

McDougall GJ, Fyffe S, Dobson P, Stewart D. 2007. Anthocyanins from red cabbage - stability to simulated gastrointestinal digestion. Phytochemistry, 68: 1285-1294.

Melton SL. 1983. Methodology for following lipid oxidation in muscle foods. Food Technology, 37: 105-111.

Oguzhan P. 2013. Effect of salting and packaging on liquidsmoked rainbow trout fillets during refrigerated storage. Afr. J. Microbiol. Res, 7(50): 5719-5725.

Pazos M, Gallardo JM, Llu1's Torres J, Medina I. 2005. Activity of grape polyphenols as inhibitors of the oxidation of fish lipids and frozen fish muscle. Food Chemistry, 92(3): 547-557.

Piccaglia R, Marotti M, Baldoni G. 2002. Factors influencing anthocyanin content in red cabbage (Brassica oleracea var capitata L f rubra (L) Thell), J Sci Food Agric 82: 1504-1509.

Pliszka B, Huszcza-Ciołkowska G, Mieleszko E, Czaplicki S. 2009. Stability and antioxidative properties of acylated anthocyanins in three cultivars of red cabbage (Brassica oleracea L. var. capitata L. f. rubra). J.S.F.A. 35-65.

Podsędek A, Sosnowska D, Redzynia M, Koziołkiewicz M. 2008. Effect of domestic cooking on the red cabbage hydrophilic antioxidants. International Journal of Food Science \& Technology, 43: 1770-1777.

Raghavan S, Hultin HO. 2005. Model system for testing the efficacy of antioxidants in muscle foods. J. Agric. Food. Chem, 53(11): 4572-4577.

$\mathrm{Sa}^{\prime}$ nchez-Alonso I, Jime'nez-Escrig A, Saura-Calixto F, Borderi'as AJ. 2008. Antioxidant protection of white grape pomace on restructured fish products during frozen storage. LWT, 41: 42-50.

Sa'nchez-Alonso I, Jime'nez-Escrig A, Saura-Calixto F, Border1'as AJ. 2007. Effect of grape antioxidant dietary fibre on the prevention of lipid oxidation in minced fish: Evaluation by different methodologies. Food Chemistry, 101: 372-378.

Shahidi F, Zhong Y. 2005. Lipid Oxidation:Measurement Methods, book.

Shantha NC, Decker EA. 1994. Rapid, sensitive, iron-based spectrophotometric methods for determination of peroxide values of food lipids. J. AOAC Int, 77(2): 421-424.

Sheeshka J, Murkin E. 2002. Nutritional Aspects of Fish Compared with Other Protein Sources. Comments on Toxicology, 8(4-6): 375-397.

Shimizu T, Muroi T, Ichi T, Nakamura M, Yoshihira K. 1997. Analysis of red cabbage colors in commercial foods using high performance liquid chromatography with photodiode array detection-mass spectrophotometry. J Food Hyg Soc Jpn, 38: 34-38.

Simon RA. 1998. Update of sulfite sensitivity. Allergy, 53(Suppl 46): 78-79 (1998).

Singleton VL, Rossi JA. 1965. Colorimetric of total Phenolics with phosphomolybdic-phosphotungistic acid reagents. Am J Enol Vitic, 16: 144-158.

Tang S, Sheehan D, Buckley DJ, Morrissey PA, Kerry JP. 2001. Anti-oxidant activity of added tea catechins on lipid oxidation of raw minced red meat, poultry and fish muscle. International Journal of Food Science and Technology, 36: 685-692. 
Vareltzis K, Zetou F, Tsiaras J. 1988. Lebensm Wiss Technol, 21: 206-211.

Venugopal V, Shahidi F. 1996. Structure and composition of fish muscle. Food Reviews International, 2: 175-197.

Watanabe T, Pongmaneer J. 1991. Quality Evaluation of Some Animal Protein Sources for Rainbow Trout Oncorhynchus mykiss. Formerly Bull. Japan. Soc. Sci. Fish, 57(3): 495-501.

Wiczkowski W, Szawara-Nowak D, Topolska J. 2013. Red cabbage anthocyanins: Profile, isolation, identification, and antioxidant activity, Food Research International 51: 303 309.

Wiczkowski W, Szawara-Nowak D, Topolska J. 2015. Changes in the content and composition of anthocyanins in red cabbage and its antioxidant capacity during fermentation, storage and stewing. Food Chemistry, 167: 115-123.

Yagiz Y, Balaban MO, Kristinsson HG, Welt BA, Marshall MR. 2009. Comparison of Minolta colorimeter and machine vision system in measuring colour of irradiated Atlantic salmon. J Sci Food Agric, 89: 728-730.
Yagiz Y, Kristinsson HG, Balaban MO, Welt BA, Raghavan S, Marshall MR. 2010. Correlation between astaxanthin amount and $a^{*}$ value in fresh Atlantic salmon (Salmo salar) muscle during different irradiation doses. Food Chemistry, 120: 121127.

Yanar Y, Celik M, Akamca E. 2006. Effects of brine concentration on shelf-life of hot-smoked tilapia (Oreochromis niloticus) stored at 4_C. Food Chemistry, 97: 244-247.

Yarnpakdee S, Benjakul S, Nalinanon S, Kristinsson HG. 2012. Lipid oxidation and fishy odour development in protein hydrolysate from Nile tilapia (Oreochromis niloticus) muscle as affected by freshness and antioxidants. Food Chemistry, 132: 1781-1788.

Yarnpakdee S, Benjakula S, Penjamras P, Kristinsson HG. 2014. Chemical compositions and muddy flavour/odour of protein hydrolysate from Nile tilapia and broadhead catfish mince and protein isolate. Food Chemistry, 142 (1): 210-216.

Yoruk R, Yoruk S, Balaban MO, Marshall MR. 2004. Machine vision analysis of antibrowning potency for oxalic acid: a comparative investigation on banana and apple. Journal of Food Science, 69(6): 281-289. 